\title{
International and Russian Practices of Preserving and Reproducing the Languages of the Small-numbered Indigenous Peoples of the North
}

\author{
Natalya N. Seredkina and Natalia P. Koptzeva* \\ Siberian Federal University \\ 79 Svobodny, Krasnoyarsk, 660041, Russia
}

Received 16.09.2018, received in revised form 04.12.2018, accepted 11.12.2018

The article describes and analyses the international and Russian practices of preserving and reproducing the endangered ethnic languages. Special attention is paid to the preservation practices of the languages of the small-numbered indigenous peoples of the North inhabiting the Krasnoyarsk Krai. The research is based on the system approach method. The research results demonstrate that due to the gradual destruction of the language transfer tradition, the "artificial" preservation practices are the most relevant for the ethnic languages. They include the creation of modern coursebooks for the languages of the small-numbered indigenous peoples of the North, based on the latest methods of ethnic language learning and teaching; publishing children's literature in the ethnic languages; linguistic documentation of languages; application of the modern information technology, including the creation of the Internet portals dedicated to the language and culture of the small-numbered indigenous peoples of the North.

Keywords: small-numbered indigenous peoples of the North, ethnic languages, coursebook, children's literature, information technology.

The article is prepared with the support of ANO Project Office for Arctic Development (PORA) within the framework of the research work under the grant "Creation of the Enets writing as a way of preservation of the unique cultural heritage of the small-numbered indigenous peoples of the North".

Research area: culturology.

Citation: Seredkina, N.N., Koptzeva, N.P. (2018). International and Russian practices of preserving and reproducing the languages of the small-numbered indigenous peoples of the North. J. Sib. Fed. Univ. Humanit. soc. sci., 11(12), 2056-2077. DOI: 10.17516/1997-1370-0373.

(c) Siberian Federal University. All rights reserved

* Corresponding author E-mail address: NevolkoN@yandex.ru; decanka@mail.ru

This work is licensed under a Creative Commons Attribution-NonCommercial 4.0 International License (CC BY-NC 4.0). 


\section{Introduction}

Since the 1990-s, the problem of language identity of the small-numbered indigenous peoples of the North of the Krasnoyarsk Krai has been in the focus of attention of various social institutions (Avdeeva et al., 2018; Berezhnova, Pimenova 2017; Kistova, Pimenova, 2018; Krivonogov, 2018; Kuzhuget, 2017; Libakova, Sertakova, 2018a; Reznikova, 2018; Zamarayeva et al., 2015, etc.). According to the sociological surveys, the role of ethnic language in the lives of the small-numbered indigenous peoples is dramatically losing momentum year after year (Kiriutkin, 2016; Krivonogov, Ermilova, 2017). Namely, the Dolgan, the Ket, the Nganasan, the Nenets, the Selkup, the Chukot, the Evenk, the Evenki and the Enets languages are at the brink of extinction. The tendency of language extinction entails negative consequences for the entire ethnic culture (Kistova et al., 2018; Libakova, Sertakova, 2018b). Firstly, with the decreasing relevance of a language in the life of its speakers, or, in the pessimistic scenario, with its extinction the intangible cultural heritage of the people is lost; it is the loss of its cultural originality which depends on the preservation of good command of the ethnic languages by the representatives of the related ethnic groups (Kiriutkin, 2016). Every language bears some relevance for ethnocultural communities as a symbol of ethnic identity, as something that incarnates their history (Anderson, 2011). Secondly, it aggravates the social maladaptation among the ethnic community representatives, which causes a risk of development of a negative ethnic identity, followed by the identification of the person with a different ethnos (Libakova et al., 2014). According to M.N. Guboglo, this is the language identity, and, particularly, the command of a language and the use of the language in everyday life that is required for an individual to confirm or to deny his/her ethnic identity (Guboglo, 2003). To resolve the problem of the endangered languages of the small-numbered indigenous peoples of the North, Siberia and the Far East of the Russian Federation, discussion platforms are organized to attract the representatives of the scientific community, authorities and the small-numbered indigenous peoples. The process involves researchers from the leading Russian universities, representatives of the Association of the Small-numbered Indigenous Peoples of the North, Siberia and the Far East of the Russian Federation, Association of the Teachers of Ethnic Languages and Literature of the Small-Numbered Indigenous Peoples of the North, Siberia and the Far East of the Russian Federation, the Ministry of Education and Science of the Russian Federation, FSBRI "Institute of Ethnic Schools of the Republic of Sakha (Yakutia)", as well as local self-administration bodies. To emphasize the relevance of the problem of research and preservation of the 
ethnic languages, it was resolved to announce the year 2019 the International Year of the Languages of Small-numbered Indigenous Peoples of the North, Siberia and the Far East.

\section{Research of the Northern small-numbered indigenous peoples' languages preservation practices}

A systematic research of the endangered languages of the peoples of Russia and, particularly, its Northern regions began in the second half of the $20^{\text {th }}$ century. Today the issue of preservation and development of the ethnic languages remains the priority of the related researches. In his article "Language Hotspots: what (applied) linguistics and education should do about language endangerment in the twenty-first century" (Anderson, 2011), Gregory D.S. Anderson expresses his concern about the extinction of many indigenous language families by the end of the $21^{\text {st }}$ century. According to the author, one of the main reasons for endangerment of the languages is the broken process of language succession between the generations. Today, children refuse to study their ethnic language as the main one and prefer not to use it in their everyday life. Considering the current situation, the researcher studies the documenting and recording of languages carried out by linguists, as well as activities of teachers as the underlying basis for the preservation of the endangered languages of the indigenous peoples.

In his work "On the languages of the small-numbered indigenous peoples of Russia", A.L. Arefiev justifies the importance of ethnic language teaching. He recognizes education as "the only efficient tool of reproduction and actual support of language command for the small-numbered indigenous peoples of Russia" (Arefiev, 2015: 77).

A number of researchers (Atknine, 1997; Turaev, 2006 et al.) tend to assume that the traditional language is maintained in the settlements where the traditional activities remain popular, since this is what the linguistic culture of the indigenous peoples is closely related to. This is why preservation and reproduction of the ethnic languages is only possible with the preservation of the traditional activities, such as reindeer breeding, fishing and nomadic lifestyle. In this regard, it is worth mentioning the nomadic kindergarten project described by N.A. Mamontova (Mamontova, 2013). The nomadic kindergarten is a project intended to actualize the interest not only for the ethnic language, but also for the traditional nomadic lifestyle with its main attributes being reindeer and chums (raw-hide tents). However, the author points out the low 
efficiency of this method for the ethnic language teaching, as, instead of the revival of the old cultural traditions, such an approach causes the folklorization of the related ethnic group. Besides the nomadic kindergarten, to attract the children and teenagers to the ethnic culture, nomadic schools and summer recreational ethnocultural children camps are arranged to teach the children through language immersion. O. Fel'de also points out that the main purpose and the distinctive feature of such projects in the communication in the ethnic mother tongue between the participants (Fel'de, 2011).

K.N. Struchkov supposes that a compulsory condition for successful revitalization of a language is using it in everyday life (Struchkov, 2005; 2011). For this reason, concentrating on the reforms and innovations in the sphere of education is not enough to solve the language preservation problem.

Among the models of preservation and development of the languages of the smallnumbered indigenous peoples of the North both traditional and alternative formats are used. A traditional format of language preservation is inclusion into school curriculum. In the last several years, teachers and curriculum developers have been working on the ethnic language teaching issues. In the year 2010, the Yukte project, a series of career guidance events and seminars for the Evenki language teachers (Andreeva, 2015) was held. The purpose of the project was to review and improve the quality of language teaching. Similar events have been held more frequently lately. In 2016, in Yakutsk the All-Russian Seminar on the methodology of contemporary ethnocultural education sourcebook development was held. The attendees shared the latest methods of teaching ethnic mother tongues of the small-numbered indigenous peoples of the North at various educational institutions. The speakers analyzed the current methods and designed some new ways of preservation of the languages of the small-numbered indigenous peoples of the North (Semenova et al., 2016).

Besides the educational format of the ethnic language preservations, the reproduction of the languages is greatly facilitated by the practice of celebrating ethnic holidays and festivals (Povorozniuk, 2014).

A number of researchers emphasize the need for accumulating efforts of scientists, ethnic language teachers, native speakers, authority bodies. N.P. Koptseva justifies the relevance of the governmental policy for the preservation of the culture of the small-numbered peoples and the ethnic language preservation (Koptseva, 2014). According to T.E. Andreeva and K.N. Struchkov, besides the focused language policy run by the authorities, the researchers' activity and the knowledge of the people are just as important (Andreeva, Struchkov, 2015). S.A. Kiriutkin regards the activity 
of the ethnic intellectual community of the Taymyr Dolgano-Nenets District of the Krasnoyarsk Krai as the underlying factor in the preservation of the language of the small-numbered indigenous peoples of the North. The cooperation between linguists and representatives of the small-numbered indigenous peoples resulted in the development of the Nganasan and the Dolgan writing systems. According to the researcher, the coursebooks, dictionaries, phrasebooks and fiction literature translated into the Dolgan, the Nenets, the Nganasan and the Enets languages are extremely important for the preservation of the languages of the small-numbered indigenous peoples of the North (Kiriutkin, 2016).

Therefore, the question of preservation and development of the languages spoken by the small-numbered indigenous peoples is the focus of the contemporary researchers, striving not only to analyze the modern linguistic situation, but also to come up with some new formats for the preservation of the endangered ethnic languages.

\section{Creation of study materials for the languages of the small-numbered indigenous peoples of the North}

Today, at the educational institutions where the ethnic languages of the smallnumbered indigenous peoples of the North are taught, there are two kinds of coursebooks: the ones published in the Soviet times and published in the 2000-s. The first ones are designed for the school students who can speak their ethnic language. Considering the fact that the students today have no command of their mother tongue, the coursebooks of the 1930-1980-s are known as methodologically obsolete (Arefiev, 2015).

The most popular coursebooks today are the ones published in the 2000 -s, the coursebooks in the Evenki, the Selkup and the Dolgan languages designed for the students of general and vocational secondary schools, higher educational institutions. The only ethnic language coursebooks available for the vocational secondary schools and higher educational institutions are the ones for the Evenki language. The coursebooks of the 2000-s, designed for secondary school students, are targeted on the teaching the ethnic language as a foreign one, which is required in the context of linguistic assimilation, when the language of everyday communication for the smallnumbered indigenous peoples of the North is Russian. It also serves as a tool for the native language studies. All the tasks and explanations concerning the ethnic language use are provided in Russian. Moreover, every coursebook includes the minimum vocabulary to be learned by the student in the process of the working on a certain part 
of the course. An integral part of the coursebooks are the illustrations accompanying the texts in the ethnic language, dialogues or vocabulary.

Some of the languages spoken by the small-numbered indigenous peoples of the North, such as the Chulym and the Enets languages, are unwritten. It creates a threat of extinction of the language in the next decades. A solution for the situation would be documenting: for instance, in 2008, the first Russian-Chulym Dictionary was prepared for printing. At the turn of the 1980-1990-s, the alphabet for the Enets language was developed. However, it has not been officially accepted or approved. Due to the threat of extinction, the creation of the Enets writing system and its establishment through the publication of the Enets folklore, coursebooks, dictionaries and phrasebooks were an essential measure. A great contribution in this process was made by I.P. Sorokina, D.S. Bolina, Z.N. Bolina, who developed modern Enets language coursebooks and dictionaries.

\section{Foreign experience of publishing children's literature in the languages of the indigenous peoples}

\section{(based on the publishing activity in the People's Republic of China)}

Publishing children's books in the languages of the small-numbered indigenous peoples today is one of the priority trends in the preservation and development of ethnic languages. It is the children's literature that creates interest for the ethnic culture in the younger generation, forming the need of the children to learn their mother tongue (Arefiev, 2015).

As the sociological surveys demonstrate, interest for folklore songs and fairy tales among the representatives of the indigenous peoples does not fade. Namely, the Evenks show a positive tendency of teaching children songs in the Evenki language (Krivonogov, Ermilova, 2017). For this reason, publishing children's literature in the ethnic language is an essential condition for keeping up the children's interest for their mother tongue, and, therefore, for preserving the language.

Abroad, the children's books in the ethnic languages of the indigenous peoples are released by large publishing centres. In Canada, those are Theytus Books and Pemmican Press, in Norway - Davvi Girji, in the People's Republic of China - China Children's Press \& Publication Group.

The experience of publishing in the languages of the indigenous peoples of China is of the greatest interest. The indigenous people of the Republic is the Han, being the majority of the population (91.51\%). The rest of the population ( $8.49 \%)$ is composed of 
55 ethnic groups including the small-numbered indigenous peoples of China and ethnic communities who migrated into the Republic during a certain period of its history. However, all of these peoples are commonly referred to as ethnic minorities (Chu, 2015).

Book publishing is a greatly developed industry in the PRC. The major percentage of the books is published in the Han language, the language of the dominating indigenous population. One of the greatest children's literature publishing centre is China Children's Press \& Publication Group (CCPPG), uniting two publishing houses: China Teenagers Press (founded in 1951) and China Children's Publishing House (founded in 1956). After the merge of the two companies specialized in literature for children and teenagers, China Children's Press \& Publication Group became the largest publishing centre of children's literature in China. Besides fiction, magazines and newspapers for different age categories are issued. For the youngest readers (0-4 years old) there is a monthly "Infant Pictorial" magazine (Fig. 1), for pre-school children (3-7 years old) there is a "Pre-School Pictorial" magazine (Fig. 2). Both projects have been approved by the Ministry of Education of the PRC.

Among the great volume of fiction books for children in China, a special attention is paid to the books on national history, classic literature and historical figures. Besides the printed books, China Children's Press \& Publication Group also issues multimedia editions for the personal computers, tablets, Kindle devices and smartphones. The wide publishing activity in the Han language significantly prevails over that in the languages of other indigenous peoples of the Republic. This branch of book publishing has its own development history.

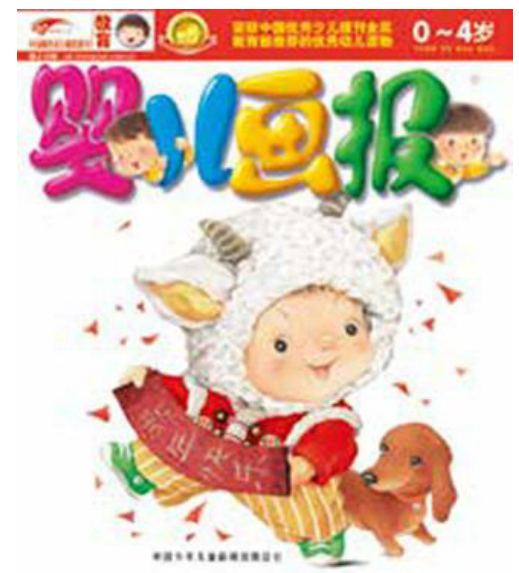

Fig. 1. Cover of the magazine for the children of the indigenous peoples of the PRC aged 0-4

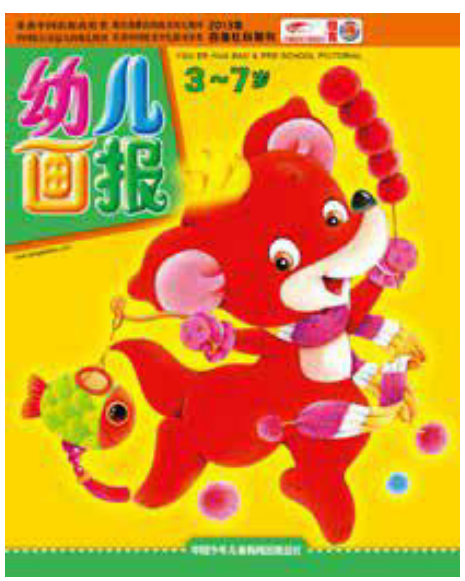

Fig. 2. Cover of the magazine for the children of the indigenous peoples of the PRC aged 3-7 
One of the most important development stages of book publishing in the languages of the small-numbered indigenous peoples in China was the creation of writing for over 14 languages spoken by 10 ethnic groups in the 1950-s (Zhang, Yang, 2017). All languages were romanized to form the alphabet base for the Chinese writing. The creation of writing facilitated the publishing of first coursebooks for the ethnic languages. One of such books was the Tujia language coursebook written by Ye Deshu in 1986. The 1980-s was the time when the language issue in China became especially relevant: the ethnic languages began to be considered as a special element of ethnic culture requiring attention of the government. Starting from the 1980-s, the revival and development of the ethnic languages began. The education services rendered to the indigenous peoples were improved: schools and universities were opened, and the salaries of teachers working in the regions of residence of the ethnic minorities were increased (Lin, 1997). One of the long-awaited but radical decisions was the introduction of bilingual education at schools. By 1995, 23 ethnic groups of the PRC, including Mongols, Uyghurs and Zhuang, had got the opportunity of studying their ethnic languages together with the Han. However, the rapid economic growth of China resulted in the change of the existing bilingual education situation. By the mid-1990-s, the system had ceased to function and remained sustained until 2008 (Zhang, Yang, 2017).

Together with the bilingual education practice, in the 1980-s some publishing activities began. In 8 provinces, ethnic publishing houses, specialized in the issue of coursebooks for the ethnic minorities, were founded. By the year 1991, books in 30 languages of 24 ethnic groups had been translated and published. There were two types of coursebooks: 1) books in ethnic languages, being the translations of the books previously published in Chinese with little addenda concerning various aspects of ethnic culture; 2) bilingual books, being texts in the ethnic language with a parallel translation into Chinese. According to the experts, the published academic literature in the languages of the minorities has a number of demotivating flaws, for example, the use of obsolete vocabulary, fairy tales and riddles with no connection to the modern everyday life. An example of such books is the coursebook "Fluent in Half a Month in Common Tujia Speaking" by Ye Deshu. "Textbook for the Tejia Language", for instance, lacks the sufficient number of exercises for language learning. Moreover, there is no sufficient amount of reference books, encyclopaedia, additional reading materials except for those published in Chinese. Even though many courses are supplied with DVD materials, such a learning practice is hardly used either in class or at home 
(Zhang, Yang, 2017). Books are usually published in the most developed minority languages, such as Mongolian, Uyghur, Yi, Zhuang languages. These languages are used not only in the family communication, but also in the social-political, economic, cultural spheres. In the 2000-s, the first endangered ethnic language coursebooks, written in international English language, saw the light. An example of such editions is a coursebook in the Northern dialect of the Tujia language. It was published in 2006 and contained sections dedicated to the phonetics, grammar, and morphology of the language (Brasset et al., 2006).

Besides the national publishing houses, a great role in the preservation and development of the languags of the indigenous peoples of China is played by the research centres. One of such centres of the Republic is the Institute of Ethnic Literature, founded within the Chinese Academy of Social Sciences. The Institute was established in Beijing in 1980. Today, there are 50 full-time employees representing 14 ethnic groups of the PRC: Mongols, Han, Tibet, Uyghur, Kyrgyz, Manchu, Korean, Daur, Evenk, Yi, the Miao, Bai, Zhuang, and Dai people. 80\% of the Institute employees are fluent in one or several languages of the ethnic minorities. The research interest of the Institute is concentrated on the ethnic literature, namely, in: 1) literature of the PRC ethnic groups, such as Mongolian, Tibet, North ethnic literature (Turkic, Uyghur, Kazakh, Kyrgyz, Manchu literatures), South ethnic literature (Dong, Zhuang, Nakhi, Yi, Bai, Miao, Dai); 2) theoretical problems related to the ethnic literature development; 3) theory of literature and contemporary literary criticism. Moreover, the researchers are engaged in the collection, recording, rewriting, translation, digitization and publishing the oral and written texts produced by the indigenous peoples of China. The Institute members have published over 130 books, including field research materials, monographs, theoretical and methodological researches, as well as translations both from the indigenous peoples' languages into Chinese and English and vice versa.

\section{Russian experience of publishing children's literature in the languages of small-numbered indigenous peoples of the North}

Supporting the publication of fiction in the languages of small-numbered indigenous peoples of the North, Siberia and the Far East of the Russian Federation is one of the priorities of the country's national policy, according to the plan of measures for implementing the Concept of Sustainable Development of the Small-numbered 
Indigenous Peoples of the North, Siberia and the Far East of the Russian Federation in 2016-2025 (dated August 25, 2016). The practice of publishing children's literature is of particular importance for the preservation and development of national languages. This is not only an opportunity to record the oral folk art of the small-numbered indigenous peoples of the North, but also an opportunity to continue the practice of involving the younger generation into the study of their native culture.

Since the end of the $19^{\text {th }}$ century, books have been published in some languages of the small-numbered indigenous peoples of the North. Those were mainly religious books, $\mathrm{ABCs}$ and dictionaries. In the Evenkitek electronic Evenk library, the following editions published in the $19^{\text {th }}$ century can be found in open access: Господа нашего Іисуса Христа $\bar{w}$ Матөея свлтое благовъствованіе на Тунгусскомъ ^зыкъ. Kazan: 1881; Краткій катихизисъ, повседневныя молитвы и Евангеліе на Святую Пасху на Тунгусскомъ языкъ. Kazan: 1881; Краткій тунгусскій словарь. Moscow: 1859; Тунгусскій букварь. Moscow: 1858. The most active publishing activity of works in the languages of indigenous peoples of the North, including children's literature, began in the $20^{\text {th }}$ century. The prerequisite for it was the creation and official approval of the writing system for ethnic languages. This process for many indigenous languages of the North is still only at the stage of its formation and development. This applies, for example, to the languages of the Kets, the Nganasans, the Enets and the Chulyms. Accordingly, there is no reason to speak about the broad publishing activity of children's literature in these languages. The writing systems of the Dolgan, the Selkup and the Evenki languages was created in the first half of the $20^{\text {th }}$ century, therefore the practice of creating works for children in these languages is much wider.

The main genres of children's ethnic literature are fairy tales and heroic epic. Along with these genres, in the Evenki, for example, poems, autobiographical novels, short stories and novels for children are published. From the second half of the $20^{\text {th }}$ century, the practice of translating children's literature from indigenous languages into Russian and from Russian into ethnic languages becomes quite relevant. Those were translations of classic Soviet literature mainly. Thus, A. Platonov made the first translation of A. Pushkin's poem "Monument" into the Evenki language, in 1939 N. Sakharov and A. Salatkin translated into their native language "The Old Woman Izergil" by M. Gorky, P. Savin translated "Stories" from the ABC of L.N. Tolstoy, A. Nemtushkin translated the novel "The Tale of the Fisherman and the Fish" into the Evenki language. Poems for children of Soviet authors A. Barto and S. Marshak 
were also translated into the Evenki language. Along with the translations of fiction, religious literature was translated. In 1995 in Stockholm, at the Institute for Bible Translation, the Evenk linguist and folklorist A.N. Myreeva translated "Stories about God" into the Evenki language.

Since the end of the $20^{\text {th }}$ century, the practice of publishing bilingual creative works has been introduced. This direction of creating texts for children is today a necessary and timely step in the context of the inevitable language assimilation of the younger generation. Svetlana Ivanovna Gayulskaya, a representative of the Evenki ethnocultural group, noted that the Evenk literature should be accompanied by a Russian translation due to the fact that "when children read, they do not understand what is written" (Koptseva et al., 2017: 41).

In order to ensure the rights of small-numbered indigenous peoples living in the Krasnoyarsk Krai to study and widely use their native language, scientists of the Siberian Federal University have developed a concept for creating up-to-date children's literature in the languages of the indigenous peoples of the North, Siberia and the Far East (Koptseva, 2017). Within the framework of this concept, the following stories were published for the Evenk children: "Who invented the Christmas tree?", "The Runaway Pancake", "The Power of Faith", "Footprints", etc. (Fig. 3a, b). The books have two versions of the text: in Evenki and in Russian, which makes the stories more comprehensible for readers. The translation into the Evenki language was made by the teachers of the Evenki language Nina Petrovna Oyogir and Nina Alekseevna Kayanovich.

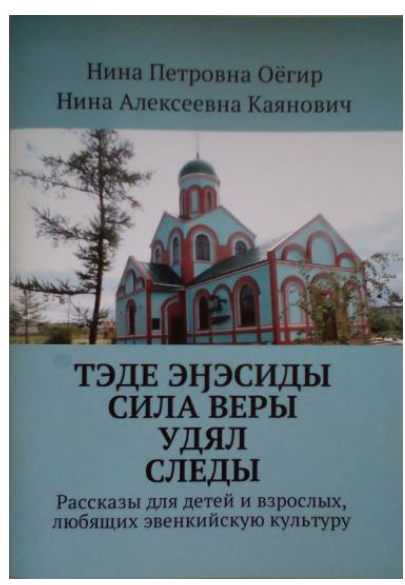

a

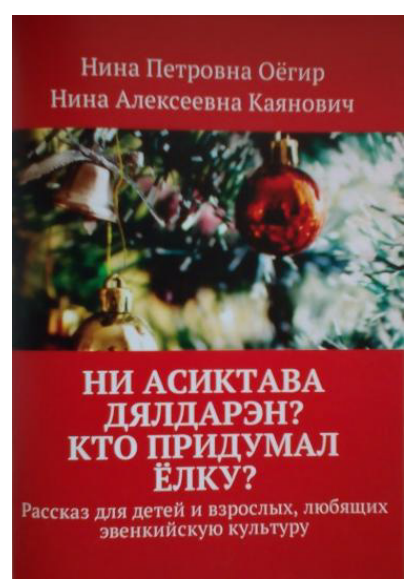

b

Fig. 3. The covers of the books for children and adults who love the Evenki culture 


\section{The practice of linguistic documentary records of the languages of small-numbered indigenous peoples of the North}

Currently, the activity of linguists involved in documenting endangered languages, is of great importance for the preservation and development of the languages of the small-numbered indigenous peoples of the North. A special role is assigned to field research during which scientists document language units with the participation of representatives of indigenous peoples who speak the national language. As noted by Gregory D.S. Anderson, linguists face the most important task of recording the words, the grammatical foundations of a language, while there is a possibility to involve the native speakers of the language (Anderson, 2011).

In the second half of the $20^{\text {th }}$ - the beginning of the $21^{\text {st }}$ centuries, the attention of linguistics has focused on expanding the subject framework and modifying research tools (Andreeva, 2013). In particular, applied linguistics uses new mathematical and statistical methods for analyzing and systematizing the material. The corpus linguistics, which makes it possible to systematize selected texts for certain parameters and objectively analyze language features, becomes especially relevant. Linguists of Tomsk State Pedagogical University are working in this field. Scientists has been conducting research in the field of structural and functional features of the languages of the indigenous peoples of Siberia for half a century already. The linguistic scholar, archeologist, ethnographer Andrei Petrovich Dulzon was the pioneer of this particular field of linguistic research. Currently, scientists have selected a corpus of folklore and everyday texts collected from 1960-1990 in the Khanty, the Selkup, the Ket, the Nganasan, the Chulym-Turkic and the Teleut languages. Archival texts were subjected to modern linguistic analysis, unified transcription, morphemic glossing, morphemic and free translation into Russian and English. In addition to linguistic, morphosyntactic analysis of texts, scholars analyze in detail the key folklore motifs of the analyzed texts. Such documentary recording of ethnic languages, their decoding using Russian and English, is of great value for the preservation and reproduction of the languages of the indigenous peoples of Siberia (Reznikova et al., 2016; Shimanskaya, Koptseva, 2018).

\section{The practice of applying modern information technology}

The scientific community is actively discussing the issue of using modern information technology for preservation, development and popularization of the languages and culture of the indigenous peoples of the North (Andreeva, 2013; 
Zhozhikov, Zhozhikova, 2013; Semenova, Banderova, 2013 and others). With the use of modern technologies, the culture of the small-numbered indigenous peoples of the North is popularized, which results in the possibility of preserving and reviving national languages. A number of projects are being implemented in this direction. Among them, there is a project on creation of audiobooks in national languages. One of these projects was implemented in the Nogliksky District Central Library named after V.M. Sangi in the Sakhalin region. 8 audiobooks in Nivkh and Uilta (Orok) languages were recorded. The texts in the national languages are read by the native speakers. Moreover, the Russian text was also recorded at the same time (Krasil'nikova, 2016).

One of the areas in the field of language preservation is the computerization of the language data. In other words, the transfer of materials into electronic form contributes not only to the preservation of the language, but also to the formation of a corpus of texts that can be used for further scientific research of the language (Andreeva, 2013). In addition, special programs (ToolBox, ELAN) allow recording of unwritten languages in electronic form based only on their sound structure. The ELAN program, for example, allows one to play not only an audio text, but also a video of the person who plays the text. Computerization makes it possible to use both textual information, audio and video materials, which significantly improves the quality of research of the language of the indigenous peoples of the North.

The practice of creating portals on the Internet about indigenous peoples of the North (Zhozhikov, Zhozhikova, 2013) is now equally popular and relevant. This project is not only the basis for archiving a large number of language material. It also contributes to the expansion of the audience willing to get acquainted with the ethnic culture of the small-numbered indigenous peoples of the North. In addition, the creation of portals performs a number of important functions for the preservation and reproduction of national languages. Firstly, the availability of the portal allows to collect and systematize the available materials on ethnic culture or cultures. The visitor of the website can quickly find the necessary information within one website. Secondly, there is an opportunity to post various kinds of materials: works of art, scientific articles, textbooks, etc., visual and auditory materials. Thirdly, the openness and availability of the website's materials contributes to the expansion of the audience interested in studying ethnic culture. Materials are both in Russian and in the national language. There is an English version of the website, which is an advantage. Fourthly, the use of new formats for preserving the national culture and the reproducing the languages contributes to the inclusion of small-numbered indigenous peoples of the 
North into the general flow of intercultural interaction. Taking into account the positive aspects of using modern technologies, scientists justify the need for each nation to present their original culture, language, historical and cultural traditions in the global Internet to transmit this information to the entire world community and their younger generation (Zhozhikov, 2012). The Arctic multilingual educational portal about the small-numbered indigenous peoples of the North (http://arctic-megapedia.ru) is a good example. It contains the most extensive material on the culture of the Chukchi, the Yukagirs, the Negidal and the Evenki. In the future, it is planned to post information about all small-numbered indigenous peoples living in the north-east of the Russian Federation.

This portal provides an open access to the courses developed for the study of the Evenki and the Yukagir languages. The section "The Evenki language for beginners" includes texts of poems, a number of video and audio materials in the ethnic language. The Evenki dictionary is available for reading. It is systematized into blocks: letters and counts, family, pronouns, housing, colours, deer, activities, pets, animals, fish, birds, insects, plants, nature, time of day, seasons, addressing people. This dictionary has been developed in accordance with the theme of 27 Evenk language lessons for beginners. A training course for learning the tundra Yukagir language is also posted on the portal. It includes a phrasebook with 57 topics. Unlike the Evenki language course, this course contains a detailed presentation of the Yukagir language and grammar. The accompanying materials include textbooks on this language containing both the visual aid and the audio of the texts presented in the textbook. There are also phrasebooks in the language of the forest Yukagirs and the Evenks posted at the website. The advantage of posting these materials is the ability to present audio recordings of study phrases.

An educational Internet resource (https://www.evenkrenaissance.com) has been created within the framework of the project "Revival of the Evenki Language", which contains information exclusively devoted to the Evenki culture. This project was implemented by researchers of the Department of Cultural Studies of Siberian Federal University. Since 2010 they have been conducting the research work on the culture of the small-numbered indigenous peoples of the North of the Krasnoyarsk Krai (Amosov et al, 2012; Reznikova, 2015; Bukova, 2016; Kirko et al., 2017 and others). The material collected in the course of numerous field studies served as the basis for creating an electronic resource about the Evenki culture. The digital format has been chosen not only because of the current trends in technological development, but also due to the 
possibility to save in electronic form, systematize and make publicly available the information that reveals the peculiarities of the Evenk culture.

The access to the resource is unlimited, anyone can visit the project website. Today the site includes 15 sections: general information about the project, audio library, scientific studies of the Evenki language, a dictionary of young reindeer herders, historical and cultural memory, archives and expeditions, information about the project team, contacts, expert interviews, interviews with native speakers, Evenki epic, Evenki tales, Evenki songs, film library, information about the project in Evenki. The main language of the website is Russian. The general information about the project, the names of the sections, the information about the Evenks and their culture are given in Russian. Such a strategy of building a website is due to the tendency of language assimilation, when Russian is recognized as the main language of communication among indigenous peoples. This ensures general availability of the materials on the Evenk culture to all who wish to get acquainted with this culture. The material in Evenki is presented in the section "Audio Library", which contains classical and modern audio recordings of the Evenki language. Classical texts such as the Bible in Evenki, fairy tales, tunes are available for listening. Among modern recordings, interviews (including video interviews) with representatives of the Evenk ethnocultural group are especially remarkable. In addition to audio recordings, the project "Renaissance of the Evenki language" contains useful background information about Evenkia, its inhabitants and the Evenki language. Here one can find news about the Evenks living outside of Evenkia. The website also contains books in Evenki, educational and artistic texts, documentaries and photographs. The section "Scientific studies of the Evenki language" provides access to scientific materials devoted to the study of the culture of the Evenks. These are scientific articles, monographs, and textbooks on the Evenki language, etc.

Internet conferences periodically held in the Yakut (since 2004) and the Evenki (since 2010) languages contribute to the involvement of the younger generation from among the indigenous peoples of the North into learning their native language, (Semenova, Banderova, 2013). An interactive application in the Yakut language for the iPhone and iPad has been developed for this purpose. This application is designed for children from 2 to 8 years.

Thus, modern information technology makes it possible not only to preserve a large amount of information about the culture of small-numbered indigenous peoples of the North, but also to make it available to everybody. Translation of ethnic languages 
into new formats (audiobooks used for creating Internet resources) promotes the ethnic culture reviving it in its new relevant quality. Such an attitude to the preservation of national languages is especially important for increasing the significance of the native language among the youth from among the indigenous peoples of the North. Creating a virtual information and intellectual space in the age of universal interaction through the Internet is today one of the effective solutions for the preservation and reproduction of ethnic languages, strengthening the language identity of young people (Reznikova et al., 2014).

\section{Conclusion}

The language situation in relation to the languages of small-numbered indigenous peoples is rather complicated: the number of native speakers of ethnic languages decreases, the younger generation prefers to speak the languages which are in demand in modern society, Russian in particular. As an additional language, young people are interested in learning English and Chinese. Therefore, in order to preserve languages that are on the verge of extinction today, the practice of "artificial" preservation of such languages becomes especially relevant. This includes publication of modern textbooks, relevant children's literature in the languages of indigenous peoples, the continuation of the practice of linguistic documentary recording of ethnic languages, including the description of the features of phonetics, grammar, morphology, syntax, and the use of modern information technology to preserve the language, including the creation of Internet portals devoted to the language and culture of indigenous peoples.

\section{References}

Amosov, A.E., Bokova, V.I., Bahova, N.A. (2012). Korennye malochislennye narody $v$ usloviiah global'nykh transformatsii. Chast' 1. Kontseptual'nye i metodologicheskie osnovy issledovaniia. Etnokul'turnaia dinamika korennykh malochislennykh narodov Krasnoiarskogo kraia [Indigenous peoples in the context of global transformations. Part 1. Conceptual and methodological basis of the study. Ethno-cultural dynamics of indigenous small-numbered peoples of the Krasnoyarsk Territory]. Krasnoyarsk, SFU, $640 \mathrm{p}$.

Amosov, A.E., Luzan, V.S. et al. (2017). Sozdanie detskoi literatury korennykh malochislennykh narodov Ehvenkiiskogo munitsipal'nogo raiona Krasnoiarskogo kraia: Analiz analogovykh proektov Kitaia, Norvegii, Kanady, drugikh stran [Creation of children's literature of indigenous small-numbered peoples of the Evenki Municipal 
District of the Krasnoyarsk Territory: Analysis of analog projects in China, Norway, Canada, and other countries]. Krasnoyarsk, SFU, KGPU.

Anderson, G.D.S. (2011). Language Hotspots: what (applied) linguistics and education should do about language endangerment in the twenty-first century. In Language and Education, 25(4), 273-289.

Andreeva, T.E. (2013). Sohranenie iazykov korennykh malochislennykh narodov Severa v kiberprostranstve: metody sovremennoi lingvistiki [Preservation of indigenous languages in cyberspace: methods of modern linguistics]. In Sbornik materialov II Mezhdunarodnoi konferentsii (Yakutsk, 12-14 iiulia 2011 g.) [Collection of materials of the II International Conference (Yakutsk, July 12-14, 2011)]. 229-233.

Andreeva, T.E. (2015). Ob osnovnykh napravleniiah izucheniia iazyka i fol'klora ehvenkov [On the main directions of studying the language and folklore of the Evenks]. In Arktika XXI vek. Gumanitarnye nauki [Arctic 21 st century. Humanities], 3(6), 85-92.

Andreeva, T.E., Struchkov, K.N. (2015). O funktsionirovanii ehvenkiiskogo literaturnogo iazyka [On the functioning of the Evenki literary language]. In Filologicheskie nauki. Voprosy teorii i praktiki [Philological Sciences. Questions of theory and practice], 7-2, 20-23.

Arefiev, A.L. (2015). On the languages of the Russia small-numbered indigenous peoples. In Sotsiologicheskie issledovaniia, 8, 75-84.

Atknine, V. (1997). The Evenki Language from the Yenisei to Sakhalin. In Ethnological Studies, 44, 109-121.

Avdeeva, Y.N., Degtyarenko, K.A., Koptseva, N.P., Luzan, V.S. (2018). Vliianie klimaticheskikh uslovii na traditsionnuiu ekonomiku korennykh malochislennykh narodov, prozhivaiushchikh $\mathrm{v}$ Taimyrskom Dolgano-Nenetskom munitsipal'nom raione (Krasnoiarskii Krai). In Sibirskii antropologicheskii zhurnal, 2, 1, 20-35.

Berezhnova, M.I., Pimenova, N.N. (2017). Istoriia formirovaniia subetnosa esseiskikh iakutov (na materiale analiza nauchnykh issledovanii i arkhiva Krasnoiarskogo kraevogo kraevedcheskogo muzeia) [The history of the formation of the sub-ethnos of the Essene Yakuts (based on the analysis of scientific research and the archives of the Krasnoyarsk Regional Museum of Local Lore)]. In Severnye Arkhivy i Ekspeditsii [Northern Archives and Expeditions], 4, 30-52.

Brasset, C., Brasset, P., Lu, M. (2006). The Tujia Language. LINCOM EUROPA, $221 \mathrm{p}$.

Bukova, M.I. (2016). Osobennosti ehtnokul'turnogo samosoznaniia ehtnicheskoi gruppy Chulymtsev, kompaktno prozhivaiushchikh na territorii derevni Pasechnoe 
Tyukhtetskogo raiona Krasnoiarskogo kraia (Tsentral'naia Sibir') [Features of ethnocultural identity of the ethnic group of Chulymians, who live compactly in the village of Pasechnoye in the Tyukhtetsky District of the Krasnoyarsk Territory (Central Siberia). In Sotsiodinamika [Socio-dynamics], 41-51.

Chu, Y. (2015). The power of knowledge: a critical analysis of the depiction of ethnic minorities in China's elementary textbooks. In Race Ethnicity and Education, 18(4), 469-487.

Chulymskii yizyk. Available at: http://ru.wikipedia.org/wiki/ (accessed 11 September 2018).

Fel'de, O.V. (2011). The Ethno-Linguistic Situation in the Krasnoyarsk Territory at the Beginning of the Third Millennium. In Journal of Siberian Federal University. Humanities \& Social Sciences, 4(7), 919-929.

Guboglo, M.N. (2003). Identifikatsiia identichnosti: Etnosotsiologicheskie ocherki [Identity Identification: Ethnosociological essays]. Moscow, Nauka, 764 p.

Kirko, V.I., Kuznetsova, Y.S., Malakhova, E.V., Vasil'ev, E.A. (2017). Otsenka kachestva zhizni zhitelei raiona Arkticheskoi zony na primere poselka Respubliki Sakha (Iakutiia) [Assessment of the quality of life of residents of the Arctic zone in the example of the village of the Republic of Sakha (Yakutia)]. In Severnye Arkhivy $i$ Ekspeditsii [Northern Archives and Expeditions], 3, 21-37.

Kiriutkin, S.A. (2016). Problema sokhraneniia iazykov korennykh malochislennykh narodov Severa i natsional'naia intelligentsiia [The problem of preserving the languages of the indigenous peoples of the North and the national intelligentsia]. In Trudy Bratskogo gosudarstvennogo universiteta. Seriia: Gumanitarnye i sotsial'nye nauki [Proceedings of the Fraternal State University. Series: Humanities and Social Sciences],1, 29-33.

Kistova, A.V., Pimenova, N.N. (2018). Ekspeditsiia v Chindatskii sel'skii sovet Tyukhtetskogo raiona Krasnoiarskogo kraia [Expedition to the Chindat Village Council of the Tyukhtetsky District of Krasnoyarsk Krai]. In Severnye Arkhivy i Ekspeditsii [Northern Archives and Expeditions], 2, 2, 30-45.

Kistova, A.V., Pimenova, N.N., Bukova, M.I. (2018). Sovremennoe sostoianie dekorativno-prikladnogo iskusstva evenkov - korennykh narodov Sibirskoi Arktiki [Modern state of decorative and applied art of the Evenks, the indigenous peoples of the Siberian Arctic]. In Severnye Arkhivy i Ekspeditsii [Northern Archives and Expeditions], 2,1, 49-56.

Koptseva, N.P. (2014). K voprosu o gosudarstvennoi politike v oblasti sohraneniia iazykov korennykh malochislennykh narodov Severa [On the issue of state policy in 
the field of preservation of indigenous languages of the North]. In Arktika i Sever [Arctic and North], 16, 34-40.

Koptseva, N.P., Zamaraeva, Y.S., Sergeeva, N.A. et al. (2017). Polevye issledovaniia $v$ Ehvenkiiskom munitsipal'nom raione: Otchet [Field research in the Evenki Municipal District: Report]. Krasnoyarsk, SFU, KGPU.

Krasil'nikova, I.V. (2016). Sozdanie audioknig dlia sokhraneniia zhivogo iazyka korennykh malochislennykh narodov Severa (nivkhov, uil'ta) [Creation of audiobooks for the preservation of the living language of the indigenous minorities of the North (Nivkh, Uilta)]. In Vestnik Dal'nevostochnoi gosudarstvennoi nauchnoi biblioteki [Bulletin of the Far Eastern State Scientific Library], 2 (71), 46-49.

Krivonogov, V.P. (2018). Budushchee sibirskikh etnosov (issledovanie detskikh vozrastnykh grupp) [The future of Siberian ethnic groups (study of children's age groups)]. In Severnye Arkhivy i Ekspeditsii [Northern Archives and Expeditions], 2, 2, 60-68.

Krivonogov, V.P., Ermilova, E.S. (2017). Dinamika ehtnicheskikh protsessov u evenkov [Dynamics of ethnic processes among the Evenks], In Sozdanie proizvedenii detskoi literatury na ehvenkiiskom iazyke [Creation of works of children's literature in the Evenki language]. 9-42.

Kuzhuget A. A. (2017). Sravnitel'nyi analiz morfofunktsional'nykh pokazatelei podrostkov 13-16 let KMNS Krasnoiarskogo kraia [Comparative analysis of morphofunctional indices of adolescents aged 13-16 years of the indigenous minorities of the Krasnoyarsk Territory], In Sibirskii antropologicheskii zhurnal [Siberian anthropological journal], 4, 6-12

Libakova N. M., Sertakova E. A. (2018a). Ekspeditsiia v poselok Surinda Evenkiiskogo munitsipal'nogo raiona. Dnevnik polevogo issledovaniia [Expedition to the settlement of Surinda of the Evenki Municipal District. Diary of field research]. In Severnye Arkhivy i Ekspedicii [Northern Archives and Expeditions], 2, 2, 6-29.

Libakova N. M., Sertakova E. A. (2018b). Korennoe zdravookhranenie tekushchee sostoianie i perspektivy (na materiale Krasnoiarskogo kraia) [Indigenous health care - current status and prospects (based on the material of the Krasnoyarsk Krai)], In Sibirskii antropologicheskii zhurnal [Siberian anthropological journal], 2, 1, 6-19.

Libakova, N.M., Sitnikova, A.A., Sertakova, E.A., Kolesnik, M.A., Ilbeykina, M.I. (2014). Modern practices of regional and ethnic identity of the Yakuts (North Asia, Russia). In Life Science Journal, 11, 12, 133-140. 
Mamontova, N.A. (2013). Na kakom iazyke govoriat nastoiashchie ehvenki? Diskussii vokrug kochevogo detskogo sada [What language do true Evenks speak? Discussions around the nomadic kindergarten]. In Ehtnograficheskoe obozrenie [Ethnographic Review], 2, 70-91.

Povorozniuk, O. (2014). Belonging to the land in Tura: reforms, migrations, and identity politics in Evenkia. In Journal of Ethnology \& Folkloristics, 8(2), 33-51.

Reznikova K.V. (2018). Sostoianie detei v Turukhanske i Farkovo (po materialam etnokul'turologicheskoi ekspeditsii Sibirskogo federal'nogo universiteta letom 2010 g.) [The state of children in Turukhansk and Farkovo (based on the materials of the ethnocultural expedition of the Siberian Federal University in the summer of 2010)]. In Severnye Arkhivy i Ekspedicii [Northern Archives and Expeditions], 2, 2, 46-59.

Reznikova, K.V. (2015). Sokhranenie traditsionnykh iazykov korennykh malochislennykh narodov kak obespechenie osnovy kul'turnogo raznoobraziia regiona [Preservation of the traditional languages of indigenous small peoples as the foundation for the cultural diversity of the region]. In Sovremennye problemy nauki $i$ obrazovaniia [Modern problems of science and education], 1-1, 1879.

Reznikova, K., Koptseva, N., Seredkina, N., Zamaraeva, J. (2016). Regional specifics of social values and their impact on Central Siberian territories' modernization (based on research of Krasnoyarsk region). In Economic Annals-XXI, 7-8 (160), 92-95.

Reznikova, K.V., Zamaraeva, J.S., Kistova, A.V., Pimenova, N.N. (2014). The current state of traditional socio-cultural practices of indigenous peoples of the North (on the example of cultures of Selkups, Nenets and Essey Yakuts). In Life Science Journal, 11, 12, 126-132.

Sbornik annotirovannykh fol'klornykh i bytovykh tekstov obsko-eniseiskogo iazykovogo areala. Kollektivnaia monografia [Collection of annotated folklore and everyday texts of the Ob-Yenisei language range. Collective monograph] (2012). Tomsk, Agraf-Press, $247 \mathrm{p}$.

Sbornik annotirovannykh fol'klornykh i bytovykh tekstov obsko-eniseiskogo iazykovogo areala. Kollektivnaia monografia [Collection of annotated folklore and everyday texts of the Ob-Yenisei language range. Collective monograph] (2015). Tomsk, TML-Press; Vajar, 344 p.

Semenova, S.S., Banderova, M.S. (2013). Sozdanie federal'nogo obrazovatel'nogo portala dlia detei korennykh malochislennykh narodov Severa, Sibiri i Dal'nego Vostoka Rossiiskoi Federatsii. Iazykovoe i kul'turnoe raznoobrazie v kiberprostranstve [Creation of a federal educational portal for children of indigenous peoples of the North, 
Siberia and the Far East of the Russian Federation. Linguistic and cultural diversity in cyberspace]. In Sbornik materialov II Mezhdunarodnoi konferentsii [Proceedings of the II International Conference]. Moscow, 331-334.

Semyonova, S.S., Bolotaeva, O.L., Lekhanov, S.B. (2016). Materialy Vserossiiskogo seminara po voprosam metodologii razrabotki sovremennogo uchebnika po ehtnokul'turnomu obrazovaniiu [Materials of the All-Russian Seminar on the methodology of the development of a modern textbook on ethno-cultural education]. Moscow, $63 \mathrm{p}$.

Shimanskaya K.I., Koptseva N.P. (2018). Istoriograficheskii obzor korennykh issledovanii za 2014-2018 gg. [Historiographical survey of indigenous studies for 20142018]. In Sibirskii antropologicheskii zhurnal [Siberian anthropological journal], 2, 1, 43-57.

Struchkov, K.N. (2005). K voprosu obucheniia ehvenkiiskomu iazyku v usloviiakh dvuiazychiia. Obrazovanie i ustoichivoe razvitie korennykh narodov Sibiri [To the question of teaching Evenki language in bilingualism. Education and sustainable development of indigenous peoples of Siberia]. Materialy Mezhdunarodnoi nauchnoprakticheskoi konferentsii [Materials of the International Scientific and Practical Conference]. Novosibirsk, 699-702.

Struchkov, K.N. (2011). Sotsiolingvisticheskie faktory iazykovoi kartiny mira evenkov v RS (YA) [Sociolinguistic factors of the linguistic picture of the Evenki world in the RS (Y)]. In Vestnik Zabaikal'skogo gosudarstvennogo universiteta [Bulletin of Transbaikal State University], 2(69), 38-44.

Turaev, V.A. (2006). Assimiliativnye protsessy u dal'nevostochnykh evenkov [Assimilation processes among the Far Eastern Evenks]. In Vestnik Dal'nevostochnogo otdeleniia Rossiiskoi akademii nauk [Bulletin of the Far Eastern Branch of the Russian Academy of Sciences], 3, 104-121.

Zamarayeva, Y.S., Kistova, A.V., Pimenova, N.N., Reznikova, K.V., Seredkina, N.N. (2015). Taymyr reindeer herding as a branch of the economy and a fundamental social identification practice for indigenous peoples of the Siberian Arctic. In Mediterranean Journal of Social Sciences, 6, 225-232.

Zhang, Q., Yang, T. (2017). Bilingual education for the Tujia: the case of Tujia minority schools in Xiangxi autonomous prefecture. In International Journal of Bilingual Education and Bilingualism, 1-19.

Zhozhikov, A.V. (2012). Iazykovoe i kul'turnoe raznoobrazie korennykh malochislennykh narodov Severa na tsifrovykh nositeliakh i v kiberprostranstve

$$
-2076-
$$


[Linguistic and cultural diversity of indigenous small-numbered peoples of the North on digital media and in cyberspace]. In Kul'turnoe nasledie Severnoi Evrazii: problemy i perspektivy osvoeniia [Cultural heritage of Northern Eurasia: problems and perspectives of development]. 111-116.

Zhozhikov, A.V., Zhozhikova, S.I. (2013). Portal o korennykh malochislennykh narodakh Severo-Vostoka Rossiiskoi Federatsii [Portal on Indigenous Peoples of the North-East of the Russian Federation]. In Sbornik materialov II Mezhdunarodnoi konferentsii (Yakutsk, 12-14 iiulia $2011 \mathrm{~g}$.) [Collection of materials of the II International Conference (Yakutsk, July 12-14, 2011)]. Moscow, 238-241.

\title{
Мировые и российские практики \\ в области сохранения и воспроизводства языков коренных малочисленных народов Севера
}

\author{
Н.Н. Середкина, Н.П. Копцева \\ Сибирский федеральный университет \\ Россия, 660041, Красноярск, пр. Свободный, 79
}

\begin{abstract}
Статья посвящена описанию и анализу мировых и российских практик, направленных на сохранение и воспроизводство этнических языков, находящихся сегодня на грани исчезновения. Особое внимание уделяется практикам сохранения языков коренных малочисленных народов Севера, проживающих на территории Красноярского края. В основе исследования лежит методология системного подхода. Результаты исследования показали, что в силу постепенного разрушения традиции передачи знаний языка от поколения к поколению своевременными сегодня являются практики «искусственного» сохранения этнических языков. Среди них создание актуальной учебной литературы для изучения языков коренных малочисленных народов Севера, учитывающей современные методы и методики преподавания этнического языка, продолжение практики издания произведений детской литературы на языках коренных народов, практика лингвистической документальной фиксации языков, практика применения современных информачионных технологий, в том числе создание Интернет-порталов, посвященных языку и культуре коренных малочисленных народов Севера.
\end{abstract}

Ключевые слова: коренные малочисленные народы Севера, этнические языки, учебная литература, детская литература, информационнье технологии.

Статья подготовлена при поддержке АНО Проектный офис развития Арктики ПОРА в рамках выполнения научно-исследовательских работ по гранту «Создание энецкой письменности как способ сохранения уникального культурного наследия коренных малочисленных народов Севера».

Научная специальность: 24.00.00 - культурология. 